\title{
Community Perception towards National Policy Plan of Zakat Deduction for Muslim Civil Servants
}

\author{
Nur Indah Riwajanti, Kartika Dewi SS. and Anik Kusmintarti \\ State Polytechnic Malang \\ Paper to be presented at International Conference of Zakat 2018 \\ 15-16 November, Universitas Gadjah Mada, Yogyakarta, Indonesia
}

ABSTRACT

This research aims to explore the perception of Muslim Civil Servants (MCS/Aparatur Sipil Negara) and zakat institutions towards national policy plan about zakat collection directly deducted from their salaries. This research adopted mixed method by collecting primary data through survey to MCS and zakat institutions in Malang area during June-August 2018. The respondents include 461 MCS collected through questionnaire and three zakat institutions as informants of direct interviews. Then the data was analyzed based on descriptive statistics and data reduction analysis. The results shows that $42 \%$ of the respondents have known this policy plan. Moreover, $60.8 \%$ of the respondents agree to pay zakat through salary deduction and answer various reasons whether they agree or not to pay zakat directly. Furthermore, the informants from zakat institutions predict that this policy might reduce the number of zakat fund from MCS. Thus, they will improve their performance in collecting and distributing zakat to get higher trust from community

Keywords: zakat, government, policy plan, Muslim civil servant, zakat institution

\section{INTRODUCTION}

Zakat is one of the Islamic pillars. Zakat, infaq and alms (sodaqa) (ZIS), as religious obligatory, is the real solution given by Islam to overcome poverty, inequality and the disproportionate distribution of income. These social issues could be addressed by optimizing and managing ZIS properly. Although the number of zakat institutions and total zakat collected has increased from year to year (Baznas, 2017), but the amount of zakat collected is insufficient to play significant a role in addressing poverty alleviation in national level. Zakat institutions must continue to strive in order to increase charity funds to enhance its role in poverty alleviation widely. Society empowerment programs should be more evenly distributed in all regions. Then, zakat can be instrumental in reducing the number of poor in Indonesia.

Given the magnitude of the number of Muslims in Indonesia, the Governor of Bank Indonesia revealed that zakat has tremendous potential that is reached 210 billion Rupiah a year; However in the year 2017 the amount of the zakat collected only 6 trillion Rupiah (CNN, January 25, 2018). Specifically for Muslim Civil Servant (MCS), zakat potential profession reached Rp 10 trillion (Damhuri, Feb 9th, 2018). Considering the huge potential of zakat fund, Finance Minister Sri Mulyani, at the 2nd Annual Islamic Conference (AIFC) in Yogyakarta on 23 August 2017, stated that the Government want to manage zakat as taxes (Kusuma, August 23, 2017). This news drew varied opinions of the community and caused 
controversy (Hartomo, 9 February 2018; Okezone, February 8, 2018).

Follow through this plan, the Minister of Religious Affairs stated that the Presidential Regulation of zakat collection for MCS is being prepared and will soon be published (Simanjuntak, 5 February 2018; Jordan, 5 February 2018). For MCS who complained that his salary cut by $2.5 \%$ to charity will be allowed to apply for objection. The plan to cuts zakat from monthly salary has generated controversy in the community. In response to this plan, the Chairman of the House Of Representatives requested that the Government to provide an explanation by calling the Minister of religious affairs, National body of Amil Zakat (Baznas) and the Minister of finance to provide detailed explanations of these plans (Simanjuntak, 6 February 2018).

The regulation by the Government on the MCS zakat actually is not new. Aceh province, on the basis of Islamic Sharia rules, already apply a withholding charities since before 2009. Research on the zakat profession was done by some researchers to analyze about the management of zakat institutions in various cities (Hadi, 2010; Hamrozi, 2007; Huda dkk, 2015; Khoirun, 2011; Maksun, 2009; Nurdiani Ekawati, and; Nurdin, 2011; Pribadi, Romadhona, 2006; Setiawan, 2011; Suciati, 2008). Research on the behavior of the payer of zakah (muzakki) performed by Kasri (2011), Huda and the Gofur (2012), Gilani (2008) and Baznas (2018) found that trust is an important factor in choosing a charity institution. Research that specifically highlights the MCS zakat profession in national policy plans has never done previously.

Based on the controversy and response appear in the mass media, then this study aims to explore community responses, especially MCS as muzakki (zakat payers) related to this national policy plan of zakat deduction. The results of this research are expected to be able to provide input for the related parties to review the policy plan so that it can deliver benefits to all parties and to minimize objection.

\section{LITERATURE REVIEW}

The rules of zakat in Aceh was created in 2004 through the Qanun number 7/year 2004 about the Management of Zakat (Nurdin, 2011:131). Zakat in Aceh also included as one source of income (Law Number 11/2006 about the Government of Aceh, article 180). This legislation also stated that ZIS and other religious property administered by the Baitul Mal. Zakat of MCS in Aceh have withheld from salary and other income.

Research done in Tulungagung showed that MCS have a diverse understanding about zakat profession, but they dutifully in paying ZIS to zakat institutions. Obligation to pay zakat profession is stated in the Decree of Regent (Hadi, 2010). In Malang area, Baitul Mal Muhammadiyah University Malang (UMM) was established based on the decision letter of the Rector in 2000. UMM have deducted of zakat profession which then managed the fund based on the principles of proper zakat management include Planning, Organizing, Actuating and Controlling (Hamrozi, 2007). Maksun (2009) revealed that employees of PLN Semarang as muzakki pay zakat voluntarily and zakat institution set up by PLN has good performance and in compliance with the concept of ulama.

Further, Suciaty (2008) discovered that there are technical problems in the management of zakat profession such as technical regulations management of zakat which is not integrated, the absence of sanctions for MCS which has not paying zakat professions, lack of public knowledge about the profession, lack of quality of staff in zakat institutions. Similarly, Sularno 
(2010) finds that obstacles in the zakat management in Yogyakarta are divided into internal and external constraints. The external constraints include lack of MCS awareness to pay zakat via Bazda District, lack of regulation to force MCS to pay zakat through Bazda Regent, lack of fiqh zakat education. The internal obstacles include the position of the less powerful Bazda to attract MCS even though in fact there is Law Number 23/ 2011 that set about Bazda. Similar results were also found in Semarang, where there is lack of community consciousness in paying zakat profession (Romadhona, 2006).

In particular in Malang area, Nurdiana and Ekawati find that the Office of Religion in Malang has deducted zakat profession from MCS monthly salary. The fund management is unique which $25 \%$ of zakat fund is distributed by Zakat Collection Unit; while $75 \%$ of zakat fund is returned to muzakki for self-distribution to relatives, neighbors, orphanages, mosques and zakat institutions. Khoirun Malang (2011) found that the management of zakat in BAZ Malang is already very well organized in all aspects, namely the collection, distribution, utilization, development and public relation. However the amount of zakat collection has decreased each year since the year 2007 until 2011.

Studies on the behavior and attitude of muzakki in helping others done by Kasri (2011) by using the survey on 300 Muslims in Indonesia. The study found that the main charity reason is to help other people who are less fortunate and religiosity motivation. In zakat distributing, most muzakki prefer informal zakat institutions rather than formal. From the survey in the four major cities in Indonesia, Baznas found that $87 \%$ of respondents has intended to pay zakat via Baznas (Baznas, 2018). Similar to previous studies, Baznas (2018) also found that the motivation for donation is the teaching and commandments of Islamic rules, social solidarity, compassion/empathy, confidence in zakat institution and family habits. In addition, factors that affect to pay zakat is attitude, subjective norms, behavior control, income, education, and knowledge (Huda and the Gofur, 2012). Jaelani (2008) also finds that the decision to pay zakat is affected by the service quality and social marketing.

\section{METHODOLOGY}

This research applies mixed approach which aims to analyze that combine quantitative and qualitative research to describe the response of MCS as zakat payer and Charity Manager of zakat institution towards the Government national policy plan to collect zakat deducted from monthly salary. This study used a survey method in Great Malang area. The primary data collected based on simple random sampling directly to MCS by using structured questionnaire and interviews to the Manager of zakat institution. The questionnaire was distributed to catch information from the MCS; while interviews was conducted to the Managers of zakat institution. The total population of zakat institution in Indonesia reached 17 national zakat institutions, includes 7 provincial zakat institution and 11 regency zakat institution (Baznas, 2017). The sample includes three managers of two national zakat institution and one regency zakat institution in Great Malang area. The total number of respondents was $461 \mathrm{MCS}$ who hold 40 types of jobs in 81 institutions; such as schools and universities, local government offices and public sector services.

For quantitative data obtained from the questionnaire, the analysis techniques used are statistical tests using descriptive statistics in SPSS. While the data from the interview is analyzed using data reduction 
technique that produce the right information to answer the research question.

\section{RESULT}

The following section present the data analysis of questionnaire to MCS and interviews to zakat institution.

\section{Questionnaires analysis}

The respondents consists of $461 \mathrm{MCS} ; 52 \%$ of the respondents are male. The majority of respondents $(85.9 \%)$ were married and have high education level $(46.3 \%$ of the respondents hold Bachelor's Degree and 31\% of the respondents hold Master and Doctoral Degree). The age of the respondents are mature, $65 \%$ of respondents aged more than 41 years old and have worked for more than 11 years $(65 \%)$. The respondents net income reached $\mathrm{Rp} 1$ million up to $\mathrm{Rp} 5$ million per month (55.5\%), between Rp 5 million up to Rp 10 million per month (30.7\%), between $\mathrm{Rp} 10$ million up to $\mathrm{Rp} 15$ million per month (9.8\%).

The respondents already knew about zakat in general $(89.7 \%)$, only $10 \%$ of respondents who did not have knowledge about zakat. The respondents who regularly pay zakat reached $92.6 \%$, while $7.4 \%$ of the respondents do not pay zakat. In particular related to zakat profession, the majority of respondents already know about zakat profession (61.1\%), while the rest (38.9\%) do not know about zakat profession. Less than half of the respondents (45\%) pay zakat profession regularly. Respondents have distributed zakat through various channels including: self-distribution (40.89\%), through zakat institution (16.9\%), Baznas $(14.17 \%)$, orphanage $(13.77 \%)$, Mosque $(9.31 \%)$ and Islamic boarding schools $(5.67 \%)$.
Regarding the Government's policy plan to deduct salaries for zakat profession, $42 \%$ of the respondents already knew the plan, while $58 \%$ of respondents do not know this plan. More than half of the respondents $(60,8 \%)$ are willing to pay zakat with such mechanisms, while $39.2 \%$ are not willing. The reason given is very diverse, whether willing or not willing.

The reason of willingness to pay zakat profession through salaries deduction

The 241 respondents provided reasons of willingness to pay zakat profession. The majority of respondents stated that paying zakat is obligatory as a Muslim. Islamic jurisprudence requires the Muslim to pay zakat when has reached nishob (minimum limit of annual income). Respondents believe that charity is important to clean up the earnings and gratitude to get blessing form Allah God Almighty. There is the rights of others in someone's wealth, thus pay zakat is a form of worship. Zakat collected can be used to help poor people, since basically a human life should please help each other. One respondent stated that:

"I've been very willing [to pay zakat
profession], because according to
the law of Islamic Shari'a, not all
income that we get [become] all
our rights, but is partly the right of
fellow Muslims who are less
capable. Because basically we are
all have the same degrees before
God ... just having a different
destiny".

For muzakki, zakat also gives the goodness and glory of life, and someone will become a better human being. Zakat is also one form of social worship and will be the savings of the hereafter. 
The respondent agreed to pay zakat through the salary deduction mechanism because it is easier, practical, no hassle, no need to transmit itself as well as avoidance of forgetting to pay zakat. Most respondents who already pay zakat profession stated that it is similar to pay by themselves or directly deducted from monthly salary. Based on the reason of limited knowledge, the respondents willing to pay zakat directly. Some respondents stated that their salaries has been deducted $2.5 \%$ for zakat since several years, for example: 15 years, 2 years; which then channeled through Baznas. With centralized zakat management, zakat funds can then be utilized in more productive, wellcoordinated, effective and efficient. One respondent replied that he was ready to pay as a form of adherence to the Government. Another reason presented by the respondents was to speed up donations to the people in need.

Although the respondents willing to pay zakat through salary deduction, but they highlight the importance of transparency and clarity in the zakat management. Respondents also expect the organizer to be amanah (trustable), orderly and purposeful in distributing of funds to the right person. The respondent also notes that the zakat funds should not be misused and should be fully utilized for the benefit of the people. Zakat professions also expected not to overlap with the other charity. Some of the respondents replied also related zakat to income tax as follows:

\section{"Because the income civil servant was cut by $15 \%$ for tax, if the zakat can reduce taxes means no problem. It is important to manage the fund properly and trustable".}

A respondent is willing to pay zakat in the amount of more than $2.5 \%$ by giving reason for paying zakat is greater than the nominal is better. In addition, they hope this policy will lead MCS has better understanding of zakat profession; sometimes to do a goodness should be forced. In addition, a respondent suggested that this policy is only a suggestion, not a compulsion because not all MCS willing to pay.

However, respondents stressed the importance of socialization/education in society before the policy is implemented, so that all society know well the purpose of this policy. In addition, a respondent highlight another side of this policy as follows:

"Cutting salary for $2.5 \%$ zakat
profession should increase
attention to the welfare of MCS,
because before this deduction,
many civil servants owe money to
bank, some even more extreme,
expenditure is less than take home
pay salary. So, the application of
the policy must be also tied with a
prudent solution".

Reasons of not willing to pay zakat profession through salary deduction

There were 132 respondents answered the reasons of not willing to pay zakat profession through salary deduction. The most widely expressed by respondents is related to the management and distribution of zakat. Respondents stated that the Manager should be transparent and trustful in managing zakat funds. Some respondents have lack of trust to the credibility of this zakat organizer. They do not believe the officer, worried about the potential corruption, thus prefer to distribute zakat directly to the poor. This respondents disagreement also due to unknown procedures for the zakat management directly.

Related to zakat distribution, the respondents believe that there is an Islamic rule who is entitled to receive zakat; they are 
concerned that zakat funds distribution might not properly targeted and not transparent. Clarity of zakat recipient becomes important issue for respondents. Because the respondents did not know who the zakat recipients are, then they are not willing to pay the zakat profession. They also suggested there are many zakat institution in distributing zakat profession.

Most respondents were not willing to pay because they already pay zakat through another institution or self-distribution. Zakat is indeed mandatory and they are willing to pay, but they prefer to distribute it directly to zakat recipients. They have calculated together with zakat maal (wealth) and have paid directly. The respondents feel more comfortable and happy to distribute it themselves to the right person. Respondents believe that zakat should be given to relatives, surrounding communities and neighbors Respondents answered that they have more information about conditions in their own residence/brother/orphanage; thus they prefer to transmit their own and show evidence of payment if needed. In addition, they can distribute it directly to people that are not yet served by zakat institution. Most respondents did not believe the Government, thus distributing zakat directly means avoiding corruption, collusion and nepotism. One respondent wrote:

"Because we know the actual
targets in the vicinity of our
residence or our relatives or
orphanage. But if professionally
managed, of course will increase
my own considerations to pay zakat
through salary deduction".

Objections were also submitted by respondents from the perspective of Islamic law. The respondent conveyed about the sturdiness of the compulsory zakat professions based on the teachings of Islam;
Zakat profession does not exist in Islamic teaching, as understood and believed by respondents. Islamic law does not mentioned about zakat profession; rather it is included in other type of zakat. The respondent also asserts there has been no agreement about zakat profession. A respondent answered:

"1. Zakat profession does not exist
within the Islamic guidance as I
understand and believe, 2. It's not
fair, because each individual has
different monthly expenditure
although they have the same net
income, 3. Do not comply with the
provisions of nishob and haul".

This law vagueness makes the respondents are not willing to pay zakat profession. In addition, the respondents argued that the monthly salary deduction does not in accordance with rule of nishob and haul (annual measurement). Most respondents also stated that their annual income has not reached nishob. Also, some of the respondents claimed to not have knowledge or understanding about zakat profession.

The respondents also submit objections reasons associated with disapproval against 'coercion' of the Government to impose zakat profession. They stated that the Government should not force MCS; zakat should not be forcefully imposed, but must match the capability of each person. In addition, respondents answered that it was not authorized by the Government to forcibly deduct it, let alone the zakat profession is not mandatory. The Government should not interfere in the zakat payment because zakat is a personal obligation to be paid with the consciousness of its own and not be forced. Another respondent mentioned that zakat payment is the personal rights which should not be interfered by others. Some respondents have 
paid zakat based on his own intention without coercion; because paying zakat should be without coercion, must be based on personal consciousness. If the Government deducts his salary, this means the Government tends to interfere individual religious activity. Respondents also stated that the salary has been deducted for taxes, so that if it is deducted for zakat, means they paid twice:

"It's a personal obligation to pay zakat, if it is imposed could reduce the meaning of the obligation itself. If it's taken, then the Government shouldn't double with taxes because the Islamic Government [during the Prophet life] used to not impose tax but directly impose zakat."

\section{Interview Analysis}

This section present the findings based on interviews analysis.

The impact of the policy plan to zakat institution

All three informants have known about this policy plan. The first informant explained that this issue has been informed by the Minister of Religious Affairs at a national meeting; but particular technical regulation has not been published. The participants were invited to give advice and input, therefore this plan still on hold, so it's still a discourse. This informant appears to have objected this plan due to his presumption that the Government will reduce its possibility to collect zakat from MCS. But the informant also convey that they remain optimistic for continued to manage ZIS. He hope there will be fairness in zakat management as all zakat institution are partner in doing fastabihul khoirot.

Furthermore, he mention that they will obey any government decision.
Therefore they will reinforce the efforts to educate communities about zakat profession by using contemporary Fiqh book published by Baznas. However, he admitted that when the regulation is applied, it will give an impact on declining opportunities to receive zakat funds from MCS. He further explained that:

"we are not just pursuing infaq ... zakat maal, but also zakat profession ... but indeed ... when a later decision that the MCS should pay through salary deduction...nationally coordinated ... Yes it would be a little close our chances ..."

But the response is then followed by the awareness to improve the quality of service to the public in the form of the creation of programs that meet the needs of the community. He further asserts that muzakki usually pay zakat to zakat institution based on their preference and trust. Further, he explained that they knew that this national zakat funds will be managed by Baznas. As an institution which is also engaged in social affair, he wanted the presence of justice for all institutions, not only provide support and convenience for one institution. He also hope that the community should be given the freedom to choose their preferred charity institutions to increase the zakat awareness. Actually, they prefer if collecting zakat profession managed such as the condition now, where the public are free to choose zakat institution. If the government would like to ensure that the MCS pay zakat, then they could show zakat payment proof as now there is NPWZ (Muzakki ID number) in SIMBA Baznas.

The second informant admitted he already obtained information about this policy plan. However, he suggested that there should be a cooperation between Baznas and 
other institutions, thus poverty alleviation efforts could be supported by others. This cooperation was highlight and could be formed in a regulation. This cooperation means providing equal opportunity and winwin solution to other zakat institutions to manage zakat funds. The focus on cooperation is proposed by this informant based on his experience that many area has not been served by Bazda.

The third informant has known this policy plan but he said that his institutions has not discussed this issue in detail. He further explained that he support this policy plan since it is the duty of the government to educate society about zakat obligation. Zakat institution exist to support the government in collecting and managing zakat funds and he said:

"So I guess... we don't worry about it ... because the market share outside of the MCS is very large... entrepreneurs pay greater zakat than MCS... so we think no problem, even we find it helpful ... anyway later if they choose to pay zakat to us is ok...if they choose Baznas is no problem... we act like that..."

Discuss further on the impact of this policy plan towards fund reduction, two informants agree that the reduction will occur. Similarly, informant B also stated that the policy will reduce the income of the zakat organization. But he saw from the other side that there is still many opportunities in collecting zakat. Somewhat different opinions presented by informant $\mathrm{C}$ who believe that this policy plan will not reduce the zakat funds collection. Instead they will try harder to educate society on the importance of zakat:
"... I guess not... does not affect us... thus we grow passion for... strong contributions to increasingly educate community about zakat".

The strategy of zakat institutions

When the policy plan is implemented, the informant will create zakat fund-raising strategies. The first informant will develop programs to collect zakat professions of noncivil servants and create a brochure about zakat profession. The second informant plan to increasingly encourage people to pay ZIS, do more visit to people (silaturahim) to prospective muzakki, make banners and put it in the right location to attract the sympathy of the community. So optimization will be done for collection of non-zakat funds, namely infak and sedekah. At this zakat institution, more funds obtained from a non-zakat, because the society pay non-zakat without having to calculate the percentage of zakat and nishob. The community choose the programs that interest them, such as waqf Quran, charity for dai (religious teacher) in remote area, distributing basic foods etc.

Thus the muzzaki will be happy because it is a direct flow, then there is a photo documentation, then there is a common prayer for the contributor. They are happy...if zakat profession right only intermittently, than that's it...finish..."

The third informant admitted that he has not thought specifically to design special strategy if this policy plan is applied. This is because the zakat fund has increased this year; if funding decreases, the strategic plan will be made. In addition, he also has a rather interesting opinions different from the other two informants: 
"this is not barriers but challenges ... challenges ... how do we continue to gain the trust of the muzzaki ... ee ... means God submit a rival for us to think ... so will not use just usual strategies ... so we will think how project marketing...education could be understood by MCS, and we are getting more trust from the people in managing this charity. I think it is precisely our grateful instead...."

Further, the third informant explained the superiority of his institution in selfsufficiency in terms of the ability to pay salaries of all employees not from zakat funds. The operational funds obtained from another source of funding such as subsidiary business namely catering business (aqiqoh), business travel for Hajj and Umrah, printing etc. The result of these efforts is more than enough to be used to manage this institutions. Therefore, this institution became the only one independent zakat institutions since 2003 and could optimally managing all the funds for charity disbursed to eligible person.

\section{DISCUSSION}

This policy plan appears to be well known by the public due to easy information accessed through online media. Based on higher number of the respondents who supported the policy and is willing to pay zakat, this implies community compliance to the Government regulation. Although most respondents still don't have knowledge and still have doubts over the legal aspect of zakat profession, but they are willing to pay the zakat through the mechanism of monthly salary deduction. This community trust deserves to be fulfilled by managing the funds in a transparent and accountable manner. This finding support other research finding in Tulungagung and
PLN (Hadi, 2010; Maksun, 2009; Suciaty, 2008) in which the MCS did not have good understanding about zakat but obey to pay zakat profession.

For respondents who are willing to pay zakat, the main reason is the awareness that paying zakat is obligatory for every Muslim. They believe that the property obtained is not entirely private rights, however there are parts of the poor to be met. This findings support the similar result of previous research on the main motivation of paying zakat is religiosity (Kasri, 2011; Baznas, 2018). This policy would ease them in fulfilling their obligation to pay zakat.

Productivity becomes an aspect which is also considered by the respondent. If the funds distributed all over Indonesia then it will provide higher benefit for poor people in larger area; so it could be more powerful in poverty alleviation programs. This is indeed being the purpose of the issuance of this policy. The interesting thing that arises is to associate tax and zakat. If zakat payment can reduce taxes, then most MCS are willing to voluntarily pay zakat profession through salary deduction.

On the other hand, the reasons given by respondents who were not willing to have salaries deduction are varied. The main reason is lack of trust that zakat will be managed with amanah and distributed to the right recipient. They understand that people in the neighborhood who are more entitled to receive zakat, like family and neighbors close by. Therefore it cannot be concluded that they do not want to pay zakat profession, yet they've been distribution zakat in a way that they most like, namely transmit themselves directly to mustahik.

Other consideration for not willing is the law about zakat profession itself is still debated among scholars (khilafiyah). They have paid zakat maal which is a combination of all annual income. The zakat measurement also became a concern because Islamic law 
specifies that zakat is calculated from nishob for one year (haul), not deducted per month. It is found that most respondent prefer to do self-distribution rather than pay zakat to zakat institutions; this is similarly to what have been found by Kasri (2011). Income deduction contain elements of 'imposing' that cannot be accepted by some respondents, because their income are less than appropriate nishob. Public should be aware that the term 'oppression' is not appropriate; the State has the right to force people to pay tithes, as already implemented at the time of the Caliph at Medina. Now, this policy also has been implemented successfully in certain area such Aceh province (Nurdin, 2011).

From the perspective of zakat institutions, they have known about the existence of this policy plan. There are reaction of objections and worried that their freedom in fund collection will becomes narrower because they will lost the opportunity to collect funds from MCS.. Although there is a bit of a concern but they had no other choice but to accept the Government's decision. But there is hope that the Government can do justice to all zakat institutions by giving equal opportunity to play a role in the society. Fairness means that society has the right to choose and decide which institution to pay zakat. Observance of zakat payment could be demonstrated by presenting proof of zakat payment. Zakat institutions expect the Government to treat them as a partner who supports the Government programs in its poverty reduction efforts and community empowerment. This goal will be achieved more quickly with good cooperation with all parties in order to reach a wider area. Zakat institution also still hope that this policy was re-examined by hearing a response from many parties.

Two informants stated that this policy will bring an impact in reducing the amount of their zakat profession funds. But they are ready to anticipate by looking for other opportunities by collecting funds from other sources. For example, by optimizing the gathering non-zakat profession, which is from infaq and sedekah.

If this policy is applied, zakat institution are ready to apply strategy. These Strategic plan includes improving educational programs about religious obligatory (infaq sedekah) to society through various media such as brochures, banners, and online media. The fund-raising and channeling programs will be better prepared so that it is more interesting for the public and enhance their trust. Focusing on independence is a very good strategy that was already done by a zakat institution. Independent means charity funds distributed entirely on society, while the operational cost of managing the institution met of business which is owned by zakat institution.

\section{CONCLUSION}

This policy plan regarding the payment of zakat through MCS salary deduction get a variety of responses from the public. This study found that most respondents are willing to pay the zakat through this mechanism. This respond was taken based on the awareness that paying zakat is obligatory for every Muslim and adherence to the Government regulation. In addition, this policy will ease in paying zakat; collected funds could be optimized and more productive for poverty alleviation and community empowerment. On the other hand, the respond of not willing are based on the reason that they are still not convinced that the zakat fund will be managed trustfully, transparently, accountably and distributed to the right recipient. Thus, they prefer to distribute their zakat to family and surrounding community. In addition, the legal standing of zakat profession still 
debatable among scholars; even the deduction were not calculated based on nishob and haul. The objections also delivered due to an element of 'compulsion' imposed by the Government. Double payment of tax and zakat also become a reason of objection.

The perception of the zakat institution obtained through the interview shows that they already knew about this policy plan and appear to be worried that there will be limitation in zakat collection. However, if this policy is manifested in the regulations and implemented, they have no other choice but to comply. The zakat institution have prepared strategies to overcome the policy by optimizing fund collection from other sources and focusing on infaq and sedekah. Furthermore, they will enhance the educational programs of religious obligatory of charity through various media such as brochures, banners, and online media. Both funding and distribution programs will be better prepared so that it is more interesting and enhancing the public trust.

\section{REFERENCES}

Baznas. (2017). Daftar Lembaga Amil Zakat. Accessed from: http://pusat.baznas.go.id/lembaga-amilzakat/daftar-lembaga-amil-zakat/

Baznas. (2018). The Giving Behaviour of Indonesian Muslim Communities: Survey in Four Cities. Jakarta: Baznas.

Damhuri, Elba. (6 Januari 2018). Pemotongan Gaji MCS Muslim untuk Zakat Didukung Accessed from: http://khazanah.republika.co.id/berita/d unia-islam/islamnusantara/18/01/06/p241vx440pemotongan-gaji-MCS-muslim-untukzakat-didukung

Damhuri, Elba. (9 Februari 2018). Lazimkah Zakat dari Potongan Gaji MCS/PNS?.
Republika Online. Accessed from: http://nasional.republika.co.id/berita/na sional $/$ newsanalysis/18/02/09/p3uh2k440lazimkah-zakat-dari-pemotongan-gajiMCSpns

Hadi, Muhammad. (2010). Problematika zakat profesi dan Solusinya, Sebuah Tinjauan Hukum Islam. Yogyakarta: Pustaka Pelajar.

Hamrozi, Mohammad. (2007). Implementasi Zakat profesi di Universitas Muhammadyah Malang. Fakultas Syariah, UIN Maliki.

Huda, Nurul dan Gofur, Abdul. (2012). Analisis Intensi Muzakki dalam Membayar Zakat Profesi. Jurnal AlIqtishad. Vol. IV., No. 2, Juli 2012. pp. 217-239.

Huda, Nurul., Novarini, Mardoni, Yosi dan Sari, Citra Permata. (2015). Zakat Perspektif Mikro Makro, Pendekatan Riset. Jakarta, Pramedia Group

Jaelani, Ahmad. (2008). Pengaruh Pengaruh Kualitas Pelayanan Dan Sosial Marketing Lembaga Amil (LAZ) Terhadap Keputusan Berzakat Muzakki (Studi Kasus Pada Rumah Zakat Indonesia). Tesis Fakultas Pasca Sarjana Universitas Indonesia.

Jordan, Ray. (5 Februari 2018). Menag Siapkan Perpres untuk Tarik Zakat 2,5\% bagi PNS Muslim. Detik.news. Accessed from: https://news.detik.com/berita/d3851409/menag-siapkan-perpres-untuktarik-zakat-25-bagi-pns-muslim

Kasri, Rahmatina Awaliah. (2013). Giving behaviors in Indonesia: motives and marketing implications for Islamic charities", Journal of Islamic Marketing, Vol. 4 Issue: 3, pp.306-324, https://doi.org/10.1108/JIMA-05-20110044

Khoirun, Nisa'. (2011). Studi Perkembangan Zakat Profesi Pegawai Negeri Sipil 
(PNS) di kota Malang. Skripsi UIN Maliki Malang.

Kusuma, Hendra. (23 Agustus 2017). Sri Mulyani Ingin Zakat Dikelola Seperti Pajak. Detik Finance. Accessed from: https://finance.detik.com/moneter/d3611323/sri-mulyani-ingin-zakatdikelola-seperti-pajak

Maksun, Muh. Mujab Ali. (2009). Optimalisasi zakat profesi dalam rangka pemberdayaan keluarga miskin. Fakultas Syariah, UIN Maliki

Nurdiani, Partin dan Ekwati, Marlina. Efektifitas Pendistribusian Zakat Profesi Pegawai Negeri Sipil Melalui Sistem Wakalah Di Kementrian Agama Kota Malang Ditinjau Dari Hukum Zakat. Jurnal Ilmiah FEB Universitas Brawijaya, Vol. 3 No. 2

Nurdin, Ridwan. (2011). Pengelolaan Zakat oleh Negara Pasca Deklarasi. Jurnal MIQOT, Vol. XXXV Issue 1, hal. 128143.

Pribadi, Ancas Sulchatifa. (2006). Pelaskanaan pengelolaan Zakat Menurut Undang-Undang Nomor 38 Tahun 1999 Tentang Pengelolaan Zakat (Studi di BAZ Kota Semarang), Tesis Program Studi Magister Kenotariatan, Universitas Diponegoro Semarang.

Ramadhona, Nur Iman. (2006). Analisa Yuridis tentang Zakat Bagi Pegawai Negeri Sipil (PNS) dilihat dari perspektif Hukum Islam. Thesis Program Pascasarjana Magister Kenotariatan Universitas Diponegoro, Semarang

Simanjuntak, Rico Afrido. (6 February 2018), DPR Minta Pemerintah Jelaskan Pemotongan Zakat PNS Muslim. Nasional Sindonews. Accessed from: https://nasional.sindonews.com/read/12 79748/15/dpr-minta-pemerintahjelaskan-pemotongan-zakat-pnsmuslim-1517888941
Setiawan, Deny. (2012). Zakat Profesi dalam Islam. Jurnal Sosial Ekonomi Pembangunan. Tahun I, No. 2, Maret 2012.

Suciaty, Henny. (2008). Zakat Profesi dalam Perspektif Hukum Islam dan undangUndang Nomor 38 Tentang Pengelolaan Zakat serta pemanfaatannya di Kota Semarang. Thesis Program Studi Magister Kenotariatan Program Pascasarjana Universitas Diponegoro, Semarang.

Okezone. 8 Februari 2018. Wacana Pungutan Zakat PNS Tuai Kontroversi, Ini Plus Minusnya. Diakses dari https://economy.okezone.com/read/201 8/02/08/320/1856453/wacanapungutan-zakat-pns-tuai-kontroversiini-plus-minusnya

Nur Indah Riwajanti

State Polytechnic Malang

Indonesia

Kartika Dewi SS

State Polytechnic Malang Indonesia

Anik Kusmintarti

State Polytechnic Malang Indonesia 